\title{
RISK FACTORS FOR GASTROESOPHAGEAL REFLUX DISEASE SYMPTOMS RELATED TO LIFESTYLE AND DIET
}

\author{
Anna Taraszewska \\ ${ }^{1}$ National Institute of Public Health - National Institute of Hygiene, \\ Department of Nutrition Education, Warsaw, Poland
}

\begin{abstract}
Gastroesophageal reflux disease (GERD) is one of the most common diseases of the upper gastrointestinal tract. The most characteristic symptom of the disease is heartburn, which occurs at least once a week. The prevalence of the disease varies and, depending on the region of the world, it may affect from a few to over $30 \%$ of an adult population. It is estimated that in Poland this disease may affect up to $35.5 \%$ of adults reporting abdominal ailments. If untreated, the disease can lead to serious complications including precancerous conditions and esophageal adenocarcinoma. Pharmacotherapy is considered as the first-line treatment in GERD patients but lifestyle modifications, including diet changes, are an important element supporting the treatment of the disease. Many factors may contribute to the development of the disease. Among them, there are non-modifiable factors such as age, sex or genetic factors and modifiable factors, e.g. lifestyle, diet, excessive body weight. This review focuses on GERD risk factors related to lifestyle and nutrition that include both dietary components and nutritional behaviour. Lifestyle risk factors that may contribute to GERD symptoms include excessive body weight, particularly obesity, moderate/high alcohol consumption, smoking, postprandial and vigorous physical activity, as well as lack of regular physical activity. Many studies indicate fatty, fried, sour, spicy food/products, orange and grapefruit juice, tomatoes and tomato preserves, chocolate, coffee/tea, carbonated beverages, alcohol as triggers for GERD symptoms. Eating habits such as irregular meal pattern, large volume of meals, eating meals just before bedtime may correlate with the symptoms of GERD. The role of lifestyle, diet and eating habits as risk factors for GERD is not clearly understood, and the results of the available studies are often contradictory. Determination of modifiable risk factors for this disease and its symptoms is important for effective dietary prevention and diet therapy of GERD.
\end{abstract}

Key words: gastroesophageal reflux disease, GERD, diet, lifestyle, risk factors, nutrition

\section{STRESZCZENIE}

Choroba refluksowa przełyku jest jedną z częstszych chorób górnego odcinka przewodu pokarmowego, a jej typowym objawem jest zgaga występująca co najmniej raz w tygodniu. Rozpowszechnienie choroby jest zróżnicowane i w zależności od regionu świata może dotyczyć od kilku do ponad 30\% dorosłej populacji. Z szacunkowych danych krajowych wynika, że choroba występuje u 35,5\% dorosłych Polaków uskarżających się na dolegliwości brzuszne. Nieleczona choroba może prowadzić do poważnych powikłań włącznie ze zmianami przednowotworowymi przełyku i rakiem gruczołowym przełyku. Podstawową metodą leczenia choroby refluksowej przełyku jest farmakoterapia, jednak modyfikacja stylu życia, w tym sposobu żywienia, jest ważnym elementem wspomagającym terapię choroby. Jej rozwojowi może sprzyjać wiele czynników. Wśród nich można wymienić czynniki niemodyfikowalne takie jak wiek, płeć, czynniki genetyczne oraz czynniki modyfikowalne m.in. styl życia, sposób żywienia, nadmierną masę ciała. W niniejszym przeglądzie skupiono się na czynnikach ryzyka choroby związanych ze stylem życia i sposobem żywienia uwzgledniającym zarówno składniki diety jak również zachowania żywieniowe. Elementy stylu życia, które mogą przyczyniać się do wystąpienia choroby i jej objawów obejmują nadmierną masę ciała, zwłaszcza otyłość, umiarkowane/wysokie spożycie alkoholu, palenie tytoniu, po posiłkową i energiczną aktywność fizyczną, ale także brak regularnej aktywności fizycznej. Wiele badań wskazuje na tłuste, smażone, kwaśne, pikantne potrawy/produkty, sok pomarańczowy i grejpfrutowy, pomidory i przetwory pomidorowe, czekoladę, kawę, herbatę, napoje gazowane, alkohol jako czynniki wywołujące objawy GERD. Nawyki żywieniowe, takie jak nieregularne spożywanie posiłków, spożywanie posiłków o dużej objętości, spożywanie posiłku przed snem, mogą korelować z objawami GERD. Rola stylu życia, diety i zwyczajów żywieniowych jako czynników ryzyka choroby refluksowej przełyku nie jest jednak jednoznacznie wyjaśniona, a wyniki dostępnych badań są często sprzeczne. Poznanie modyfikowalnych czynników ryzyka choroby refluksowej przełyku i jej objawów ma znaczenie praktyczne i jest istotne w celu realizacji skutecznej dietoprofilaktyki i dietoterapii choroby.

Słowa kluczowe: choroba refluksowa przetyku, dieta, styl życia, czynniki ryzyka, żywienie

Corresponding author: Anna Taraszewska, Narodowy Instytut Zdrowia Publicznego - Państwowy Zakład Higieny, Zakład Edukacji Żywieniowej, ul. Chocimska 24, 00-791 Warszawa, tel. +48 22 5509835, e-mail: ataraszewska@pzh.gov.pl

(C) Copyright by the National Institute of Public Health - National Institute of Hygiene 


\section{INTRODUCTION}

Gastroesophageal reflux disease (GERD) is one of the most common diseases of the upper gastrointestinal tract. It develops as a result of the reflux of gastric contents into the esophagus, which may (but does not have to) cause inflammation of the esophageal mucosa and cause unpleasant symptoms. The most characteristic esophageal symptom of the disease is heartburn, which occurs at least once a week. In the definition of the disease, however, the multiformity of disease symptoms was indicated, distinguishing among them esophageal and extra-esophageal symptoms. The extra-esophageal symptoms include i.a. chest pain not related to heart disease, paroxysmal cough (mainly at night), sore throat, gingivitis or damage to tooth enamel [77]. In clinical practice, a distinction between the Non-Erosive Reflux Disease (NERD) and the Erosive Reflux Disease (ERD) is made. NERD is more common and may affect up to $70 \%$ of GERD patients $[5,38]$. If untreated, the disease can lead to complications such as esophageal stricture, gastrointestinal bleeding, precancerous conditions (Barett's Esophagus) and esophageal adenocarcinoma [15].

Epidemiological data show that the disease spreads differently around the world. Symptoms of the disease are found in approximately one in five people in North and South America, and one in seven in Australia. The lowest percentage of patients is recorded among the inhabitants of Asian countries $(<10 \%)$. In Europe, GERD may affect $15-21 \%$ of the population depending on the region [29]. It is estimated that in Poland this disease may affect up to $35.5 \%$ of adults reporting abdominal ailments [88]. A global pooled prevalence study estimated that about $14 \%$ of the world population experienced at least weekly reflux symptoms $[29,60]$.

Multiple mechanisms are involved in the pathogenesis of GERD including: motor abnormalities, such as impaired lower esophageal sphincter (LES) resting tone, transient lower esophageal sphincter relaxations (TLESRs), impaired esophageal acid clearance and delayed gastric emptying [15, 41].

Pharmacotherapy, most often with proton pump inhibitors (PPIs), is considered the first-line treatment in GERD patients. Modification of lifestyle, including diet changes, is an important element supporting the treatment of the disease.

\section{RISK FACTORS FOR GERD}

Many factors may contribute to the development of the disease. Among them, there are non-modifiable factors such as age, sex or genetic factors and modifiable factors, e.g. lifestyle, diet, excessive body weight.
Gastroesophageal reflux disease can occur in adults and children, and the risk of GERD symptoms in the adult population increases with age, which is confirmed, among others, by the results of metaanalysis published in recent years. Eusebi et al. demonstrated that the risk of disease symptoms in people aged over 50 was $30 \%$ larger compared to younger respondents (OR 1.32; 95\% CI 1.12 - 1.54) [29]. Nirwan et al. confirmed that the prevalence of GERD was higher in people aged 35-59 years than those aged 18-34 years but was slightly lower in those aged $\geq 60$ years compared with those aged 35-59 years [60].

According to some authors, the disease occurs with a similar frequency in men and women $[51,88]$. However, several studies have shown that women are more likely to develop gastroesophageal reflux disease $[29,34,60]$, but reflux oesophagitis is more common in men $[11,14,43,62,79,80]$.

The results of studies conducted in the population of mono- and dizygotic twins suggest the role of genetic factors in the pathogenesis of GERD. According to the data from the Swedish Twin Registry and the British Twin Registry, the presence of GERD is associated with a genetic factor in $31 \%$ and $43 \%$ of them, respectively $[4,10,52]$.

This review focuses on GERD risk factors related to lifestyle and nutrition that include both dietary components and nutritional behaviour.

\section{RISK FACTORS RELATED TO LIFESTYLE}

The literature highlights the role of selected lifestyle variables as risk factors for GERD symptoms.

\section{Smoking}

Many studies concern the influence of smoking on the occurrence of disease symptoms $[29,32,34,59$, $60,83,85,87]$. Zheng et al. confirmed that smoking is a risk factor for reflux occurring at least once a week, and the risk increases with the number of cigarettes smoked per day and is higher in male smokers compared to female smokers. Smoking more than 20 cigarettes a day increased the risk of frequent reflux in women by $37 \%$, in men - by $53 \%$ compared to non-smokers [87]. Similar observations were made by Nillson et al., who showed a $70 \%$ increase in the risk of heartburn and regurgitation in daily smokers, who smoked more than 20 years, compared to non-smokers [59]. The pooled prevalence of GERD according to smoking habits in meta-analysis of Nirwan et al. showed that subjects who currently smoke had a higher prevalence of GERD (18.40\%) compared with ex-smokers $(16.83 \%)$ and non-smokers $(15.55 \%)$. The OR in current smokers compared with non-smokers was 1.04 
(95\% CI 1.00-1.09) but it was statistically insignificant [60]. In other meta-analysis of 30 studies that reported the prevalence of gastrooesophageal reflux symptoms according to smoking status the pooled prevalence of gastrooesophageal reflux symptoms was higher in current smokers compared with non-smokers $(19.6 \%$ vs $15.9 \%$ ). The OR in those who smoked currently compared with those who did not was 1.26 (95\% CI 1.04-1.52) with significant heterogeneity between studies [29].

\section{Physical activity}

Many studies show a correlation between physical activity and GERD, but their results are ambiguous [22, $25,53,59,87]$. It seems that the influence of physical activity on the occurrence of disease symptoms may be related, with the type of exercise, level of activity, and its duration. It has been found that some types of activity, such as weight lifting, significantly increase heartburn compared to others, such as recreational jogging or cycling [12, 44]. In healthy volunteers and sportsmen, it has been shown that postprandial physical activity and intense exercise physical activity favour the development of GERD symptoms [72, 78]. Zheng et al. demonstrated that there is a relationship between the occurrence of disease symptoms and occupational physical activity. The authors concluded that manual work involving lifting or carrying heavy objects was more favourable to GERD symptoms than sedentary work [87]. Nocon et al. showed that people with GERD symptoms are less active than people without symptoms [61], and lack of physical activity, defined as exercise less than once a month, was defined as a risk factor for GERD, especially in women [53]. A positive correlation between the occurrence of symptoms and the lack of physical activity was also found in the study by Yamamichi et al. [85].

Scientific evidence also points to a protective effect of physical activity [21, 59, 64, 87]. It was shown that regular, recreational physical activity such as running and swimming reduced the risk of GERD symptoms, and the degree of reduction depended on the frequency and duration of activity [59, 64]. A lower risk of postprandial GERD symptoms was observed in people who were walking after dinner compared to people who were lying down after a meal [72]. Djärv et al. showed that in healthy weight subjects with GERD, high physical activity reduced the risk of symptoms compared to low physical activity, but this effect disappeared after adjusting for confounding factors such as sleep problems and comorbidities. Moderate physical activity decreased the risk of GERD symptoms in obese people, and in overweight people no influence of physical activity on the symptoms of the disease was observed. Possible protective mechanism of regular physical activity may be related to the strengthening of the diaphragm and thus the improvement of the functioning of the natural anti-reflux barrier. Regular physical activity is also conducive to maintaining the energy balance and improve weight control [19].

\section{Alcohol consumption}

Study results concerning the influence of alcohol consumption on the occurrence of GERD symptoms are inconsistent $[2,26,34,35,47,59]$. Some studies confirm the influence of alcohol consumption on the induction of symptoms of the disease, and the negative influence of alcohol on the esophageal mucosa, its motor function and the intensification of gastric juice secretion is described as a possible explanation for the association of alcohol consumption with the occurrence of GERD symptoms [46, 49]. The results of the metaanalysis of data from different regions of the world indicate that the pooled prevalence of GERD according to alcohol intake showed a similar GERD prevalence in those who do not drink alcohol or have a low intake of alcohol compared with those who have a moderate to high intake of alcohol. The OR for GERD in those with a moderate/high intake of alcohol compared with those who do not drink alcohol or have a low intake of alcohol was 1.07 (95\% CI 1.02-1.12; $p=0.004)$ [60].

\section{Excessive body weight}

Well-documented risk factor for GERD related to lifestyle is excess body weight, especially obesity $[8,16,19,23,27,34,36,48,50,54,55,64,81]$. Hallan et al. showed that the risk of GERD increases by $30 \%$ with the increase in BMI by one unit, regardless of the initial value of this indicator [34]. The results of the 24-hour $\mathrm{pH}$-measurement study showed that people with a BMI $>30 \mathrm{~kg} / \mathrm{m}^{2}$ compared to those with a BMI $<25 \mathrm{~kg} / \mathrm{m}^{2}$ were significantly more likely to have an increase in the number and a longer duration of acid reflux episodes, regardless of conditions of measurement (postprandial measurement, supine position, vertical position) [23]. A positive correlation was found between increased BMI ( $\geq 25 \mathrm{~kg} / \mathrm{m} 2)$ and the risk of esophagitis [9, 11]. In meta-analysis of Nirvan et al. stratified pooled prevalence of GERD by BMI showed an increase in GERD prevalence as BMI increased. The lowest prevalence of GERD was for those with a BMI $<18.5(6.64 \%, 95 \%$ CI $3.40 \%-110.82 \%$ ), whereas the highest prevalence of GERD was seen in those with a BMI $\geq 30.0(22.63 \%$, 95\% CI 17.33\%-128.41\%) [60]. Eusebi at al. showed, that the pooled prevalence was higher in obese subjects compared with non-obese $(22.1 \%, 95 \% \mathrm{CI}$ $17.4 \%-27.2 \%$ vs $14.2 \%, 95 \%$ CI $10.8 \%-18.0 \%$ ) and OR in obese compared with non-obese subjects was 1.73 (95\% CI 1.46 to 2.06 ), but there was significant heterogeneity between studies [29]. 


\section{Risk factors related to diet}

Many symptoms of GERD frequently appear after meals, which suggests that the composition of diet may also play a role in promoting symptoms of the disease [31]. However, it should be noted that the study results are often inconsistent.

Many studies indicate fatty, fried, sour, spicy food/ products, orange and grapefruit juice, tomatoes and tomato preserves, chocolate, coffee/tea, carbonated beverages, alcohol as triggers for GERD symptoms $[24,40,59,60,61,64,73]$.

Study results indicate a role of fat/fatty meals in the induction of GERD symptoms [24, 63, 73], and high-fat meals are considered a strong predictor of night heartburn [6]. Fatty foods lower LES pressure, increase TLESRs, and delay gastric emptying $[6,57]$. It was shown that such meals reduced LES pressure significantly more than meals with protein as the dominant component [56]. Shapiro et al. observed that a higher percentage of energy from dietary fat, as well as increased consumption of saturated fatty acids and cholesterol, were significantly associated with a higher risk of reflux episodes [73]. Fat may also contribute to the symptoms of the disease indirectly. It is the most energetic component of food, which excessive consumption may disrupt energy balance and promote the development of overweight and obesity [1], and obesity is considered as an independent risk factor for GERD. Several studies did not confirm the role of fat in generating GERD symptoms, but authors of the studies did not take into account that the subjects with GERD could intentionally avoid eating fatty foods because of fear of disease symptoms, which could have an impact on the determined cause-effect relationships [13, 65, 70, 76, 82].

Only several studies have confirmed the effect of consuming orange/grapefruit juice, tomato juice, tomato products and raw tomatoes on the intensification of heartburn, which was explained by the irritating effect of the acidic $\mathrm{pH}$ of these products on the esophageal mucosa $[18,58,63]$.

Many GERD patients report the presence or worsening of heartburn after eating spicy food, including chili pepper. It has been suggested that some of the symptoms associated with chili pepper consumption could be caused by the stimulation of nerve endings in the esophageal mucosa by capsaicin contained in hot peppers [7, 37, 69, 74].

Increased heartburn was also observed after consuming chocolate, and a reduction in LES pressure was indicated as the possible cause [63]. However, several observational studies did not confirm the relationship between chocolate consumption as trigger of GERD symptoms [21, 76].

GERD patients report the occurrence of heartburn after coffee consumption, and some of them also after tea consumption $[3,26,53,63,74]$. In a study of monozygotic twins, coffee consumption was identified as a moderate risk factor for GERD symptoms, but only among women. However, after adjusting for BMI, smoking and physical activity this factor lost the power [87]. In study of Nirwan at al., pooling prevalence of GERD according to intake of coffee/ tea revealed a higher GERD prevalence in subjects with a moderate/high intake of coffee/tea than those with a low/none intake (OR 1.47, 95\% CI 1.36-1.59) [60]. On the basis of studies using the measurement of esophageal $\mathrm{pH}$ and/or pressure in the LES, it was found that coffee and tea consumption significantly decreased LES pressure and increased reflux [67]. At the same time, many studies have shown no relationship between coffee or tea consumption and the occurrence of GERD symptoms [17, 21, 53, 55, 59, 61, 64]. Correct conclusions about the relationship between coffee/tea consumption and the occurrence of GERD symptoms are hindered by the fact that these drinks are often consume with or after a meal. Some authors even conclude that due to the contradiction of data and unclear relationship between the occurrence of GERD symptoms and coffee/tea consumption, it should not be routinely recommended to avoid coffee/ tea consumption in GERD patients [31].

A significant percentage of people with GERD (up to $50 \%$ depending on the study) report the occurrence of heartburn, regurgitation after consumption of carbonated beverages [30, 63, 75]. Several studies have shown that carbonated beverages most likely affect the occurrence of symptoms by lowering LES pressure and increasing TLESRs. In the meta-analysis of research from different regions of the world, developed by Nirwan et al. subjects with a moderate/ high intake of carbonated drinks had a higher pooled prevalence of GERD than those with low/none intake (OR 1.29, 95\% CI 1.14-1.46; $p=0.0001$ ) [60].

\section{Risk factors related to eating behaviours}

According to the available data, eating habits such as fast, irregular eating, snacking, large volume of meals, eating meals just before bedtime may correlate with the symptoms of GERD [28, 33, 84, 85].

Irregular consumption of meals, including frequently skipping breakfast, the habit of snacking at night, eating dinner just before bedtime, may be a risk factor for typical symptoms of GERD, increasing the probability of their occurrence by up to $20 \%[28,74,85]$.

According to healthy nutrition recommendations, the recommended number of meals is 4 to 5 a day [42]. However, there is little data in the literature regarding the relationship between the occurrence of GERD symptoms and the number of meals [28, 40, 68]. In study by Jarosz and Taraszewska, based on univariate logistic regression analysis, it was shown that eating 
1-2 meals a day was a risk factor for GERD (OR 3.50, 95\% CI: $1.75-6.98 ; \mathrm{p}<0.001)$, however, this factor was losing power in the multivariate analysis [40 ]. It can be assumed that eating a small number of meals a day results in their greater volume, and the relationship between a large volume of meals and inducing reflux has been demonstrated in studies conducted, among others by Iwakiri et al. or Salvia et al. [39, 71]. In Jarosz and Taraszewska study eating one, big meal in the evening instead of dinner and super was risk factor for GERD but only in univariate logistic regression analysis (OR 1.80, 95\% CI: $1.05-3.11 ; p=0.034)$. In multivariate logistic regression analysis this factor was not statistically significant [40]. In study by Pehl et al. [65] it was found that volume of meals influenced the appearance/ intensification of reflux episodes by increasing the intra-gastric pressure caused by the retention of food in the stomach. Consumption of a heavy meal contributes to the stretching of the stomach and, consequently, may induce reflux due to transient lower esophageal sphincter relaxations [20, 41].

Eating a meal (especially high in fat) shortly or just before bedtime is considered as a possible risk factor for reflux symptoms [28, 33, 45, 66, 85, 86]. The recommendation to eat last meal at least 2-3 hours before bedtime may have particularly positive results in patients with night heartburn problem [45]. Fujiwara et al. showed that patients who went to bed within 3 hours after a meal were 7 times more likely to develop heartburn than those who consumed their last meal at least 4 hours before bedtime [33]. Increasing the time between the last meal and bedtime has been shown to reduce the risk of heartburn. The short time between supper and bedtime is probably associated with more food remaining in the stomach, which may result in increased LES pressure in the supine position, deterioration of its functioning and, as a result, favour the reflux [28].

The relationship between the rapid food intake and the occurrence of reflux symptoms is not clear $[28,74,84,85,86]$. The relationship between the rate of eating and the occurrence of reflux symptoms has been confirmed in a few studies. Wildi et al. showed that eating a standard meal in 5 minutes by healthy volunteers generated a statistically significantly greater number of reflux episodes in the first postprandial hour than eating the same meal in 30 minutes. Due to the fact that the functioning of the natural anti-reflux barrier is impaired in people with GERD, the authors suggested the need for research in GERD patients to assess whether slow eating could constitute a "lifestyle modification" aimed at reducing unpleasant symptoms [84]. Results of study conducted by Yamamichi et al. in Japanese, adult population showed an obvious correlation between GERD symptoms and dietary habits such as habit of quick eating, having dinner a few hours before going to bed, the habit of eating a midnight snack and frequently going without breakfast. I was even suggested that these four diet-related factors presented more significant effects than alcohol consumption or smoking on GERD symptoms [85].

As the authors of some of mentioned studies noted, their conclusions may have been distorted by the influence of other factors, e.g. a large volume of meals or excessive body weight of some of the respondents. Therefore, further studies are needed to assess the relationship between the rate of eating and the occurrence of GERD symptoms.

\section{SUMMARY}

The role of lifestyle, diet and eating habits as risk factors for GERD is not clearly understood, and the results of research conducted in this direction worldwide are often contradictory. This may result not only from methodological differences, but also from geographic or cultural differences (e.g. culinary traditions), which may influence the diet of the surveyed populations. Based on the available data, patients with GERD should be advised, as part of nonpharmacological therapy, to normalize body weight in overweight/obese people, smoking cessation, reduce/ eliminate alcohol consumption and avoid eating meals just before bedtime. It is also worth to consider reducing or eliminating consumption of products defined as potentially refluxogenic, i.e. fatty, fried, sour, spicy food/products, orange and grapefruit juice, tomatoes and tomato preserves, chocolate, coffee/tea, carbonated beverages. Moderate, regular physical activity is also recommended. Lifestyle and diet are modifiable factors, therefore further research and analysis of disease risk factors related to diet, eating habits and lifestyle are advisable. An additional reason is the significant spread of GERD in the world, especially in highly developed countries. Determination of modifiable risk factors for this disease and its symptoms is important for effective dietary prevention and diet therapy of GERD.

\section{REFERENCES}

1. Acosta A., Camilleri M.: Gastrointestinal Morbidity in Obesity. Ann N Y Acad Sci 2014;1311:4256.

2. Akiyama, T., Inamori, M., Iida, H., Mawatari H., Endo H., Hosono K., Yoneda K., Fujita K., Yoneda M., Takahashi H., Goto A., Abe Y., Kobayashi N., Kubota K., Saito S. Nakajima A.: Alcohol consumption is associated with an increased risk of erosive esophagitis and Barrett's epithelium in Japanese men. BMC Gastroenterol 2008;8(1):58-64.

3. Alkhathami A.M., Alzahrani A.A., Alzahrani M.A., Alsuwat O.B., Mahfouz M.E.M.: Risk factors for 
gastroesophageal reflux disease in Saudi Arabia. Gastroenterol Res 2017;10(5):294-300.

4. Argyrou A., Evangelia Legaki, Koutserimpas C., Gazouli M., Papaconstantinou I., Gkiokas G., Karamanolis G.: Risk factors for gastroesophageal reflux disease and analysis of genetic contributors. World J Clin Cases 2018;6(8):176-182.

5. Bayerdorffer, E., Bigard M.A., Weiss W., Mearin F., Rodrigo L., Dominguez-Muñoz J.E., Grundling H., Persson T., Svedberg L.E. , Keeling N. , Eklund S.: Randomized, multicenter study: on-demand versus continuous maintenance treatment with esomeprazole in patients with non-erosive gastroesophageal reflux disease. BMC Gastroenterol 2016;16:48-59.

6. Becker D.J., Sinclair J., Castell D.O., Wu W.C.: A comparison of high and low fat meals on postprandial esophageal acid exposure. Am J Gastroenterol 1989;84:782-786.

7. Bolin T.D., Korman M.G., Hansky J., Stanton R.: Heartburn: community perceptions. J Gastroenterol Hepatol 2000;15:35-39.

8. Bor S., Lazebnik L.B., Kitapcioglu G., Manannikof I., Vasiliev Y.: Prevalence of gastroesophageal reflux disease in Moscow. Dis Esophagus 2016;29:159-165.

9. Cai N., Ji G.Z., Fan Z.N., Wu Y.F., Zhang F.M., Zhao Z.F., Xu W., Liu Z.: Association between body mass index and erosive esophagitis: a meta-analysis. World J Gastroenterol 2012;18(20):2545-2553.

10. Cameron A.J., Lagergren J., Nyren O., Nyren O., Locke G.R., Pedersen N.L.: Gastroesophageal reflux disease in monozygotic and dizygotic twins. Gastroenterol 2002;122:55-59.

11. Chih P.C., Yang Y.C., Wu J.S., Chang Y.F., Lu F.H., Chan C.J.: Overweight associated with increased risk of erosive esophagitis in a non-obese Taiwanese population. Plos One 2013;8(11):1-7.

12.Collings K.L., Pierce Pratt F., Rodriguez-Stanley S., Bemben M., Miner P.B.: Esophageal reflux in conditioned runners, cyclists, and weightlifters. Med. Sci. Sports Exercise 2003;35(5):730-735.

13. Colombo P., Mangano M., Bianchi P.A., Penagini $R$. Effect of calories and fat on postprandial gastroesophageal reflux. Scand J Gastroenterol 2002;37:3-5.

14. Crews N.R., Johnson M.L., Schleck C.D., Enders F.T., Wongkeesong L.M., Wang K.K., Katzka D.A., Iyer P.G.: Prevalence and predictors of gastroesophageal reflux complications in community subjects. Dig Dis Sci 2016;61:3221-3228.

15. Dąbrowski A.: Choroba refluksowa przełyku. W Wielka Interna. Gastroenterologia, cz. 2 (red. A. Antczak, M. Myśliwiec, P. Pruszczyk; red. tomu A. Dabrowski), Medical Tribune Polska, Warszawa 2011;10-27 (in Polish)

16.Delgado-Aros S., Locke G.R. 3rd, Camilleri M.C., Talley N.J., Fett S., Zinsmeister A.R., Melton L.J.: Obesity is associated with increased risk of gastrointestinal symptoms: a population-based study. Am J Gastroenterol 2004;99:1801-1806.

17. Diaz-Rubio M., Moreno-Elola-Olaso C., Rey E., Locke G.R., Rodriguez-Artalejo F.: Symptoms of gastro- esophageal reflux: prevalence, severity, duration and associated factors in a Spanish population. Aliment Pharmacol Ther 2004;19:95-105.

18. Dibley L.B., Norton C.H., Jones R.: Don't eat tomatoes: patient's self-reported experiences of causes of symptoms in gastro-oesophageal reflux disease. Family Practice 2010;27:410-417.

19. Djärv T., Wikman A., Nordenstedt H., Johar A., Lagergren J., Lagergren P.: Physical activity, obesity and gastroesophageal reflux disease in the general population. World J Gastroenterol 2012;18(28):37103737.

20.Dodds W.J., Dent J., Hogan W.J., Helm J.F., Hauser R., Patel G.K., Egide M.S.: Mechanisms of gastroesophageal reflux in patients with reflux esophagitis. New England J Med 1982;307:1547-1552.

21. Dore M.P., Maragkoudakis E., Fraley K., Pedroni A., Tadeu V., Realdi G., Graham D.Y., Delitala G., Malaty H.M.: Diet, lifestyle and gender in gastro-esophageal reflux disease. Dig Dis Sci 2008;53:2027-2032.

22.El Serag H.: The association between obesity and GERD: a review of the epidemiological evidence. Dig Dis Sci 2008;53(9):2307-2312.

23.El-Serag H., Graham D.Y., Satia J.A., Rabeneck $L .:$ Obesity is an independent risk factor for GERD symptoms and erosive esophagitis. Am J Gastroenterol 2005;100:1243-1250.

24.El-Serag H., Satia J., Rabeneck L.: Dietary intake and the risk of gastroesophageal reflux disease: a cross sectional study in volunteers. Gut 2005;54:11-17.

25. Emerenziani S., Zhang X., Blondeau K., Silny J.: Gastric fulness, physical activity and proximal extent of gastroesophageal reflux. Am J Gastroenterol 2005;100:1251-1256.

26.Ercelep O.B., Caglar E., Dobrucali A.: The prevalence of gastroesophageal reflux disease among hospital employees. Dis Esophagus 2014;27:403-408.

27. Eslick G.D.: Gastrointestinal symptoms and obesity: a meta-analysis. Obes Rev 2012;13:469-479.

28. Esmaillzadeh A., Kashteli A.H., Feizi A.: Patterns of dietrelated practices and prevalence of gastro-esophageal reflux disease. Neurogastroenterol Motil 2013:25:831841.

29.Eusebi L.H., Ratnakumaran R., Yuan Y., SolaymaniDodaran M., Bazzoli F., Ford A.C.: Global prevalence of, and risk factors for gastroesophageal reflux symptoms: a meta-analysis. Gut 2017;67:430-440.

30.Feldman M., Barnett C.: Relationships between the acidity and osmolality of popular beverages and reported postprandial heartburn. Gastroenterol. 1995;108:125131.

31. Festi D., Scaioli E., Baldi F., Vestito A., Pasqui F., Di Biase A.R., Colecchia A.: Body weight, lifestyle, dietary habits and gastroesophageal reflux disease. World $\mathrm{J}$ Gastroenterol 2009;15:1690-1701.

32.Fujiwara Y., Kubo M., Kohata Y., Machida H., Okazaki H., Yamagami H., Tanigawa T., Watanabe K., Watanabe T., Tominaga K., Arakawa T.: Cigarette smoking and its association with overlapping gastroesophageal reflux disease, functional dyspepsia, or irritable bowel syndrome. Intern Med 2011;50(21):2443-2447. 
33. Fujiwara Y., Machida A., Watanabe Y., Shiba M., Tominaga K., Watanabe T., Oshitani N., Higuchi K., Arakawa T: Association between dinner-to-bed time and gastro-esophageal reflux disease. Am J Gastroenterol 2005;100:2633-2636.

34.Hallan A., Bomme M., Hveem K., Møller-Hansen J., Ness-Jensen E.: Risk factors on development of newonset gastroesophageal reflux symptoms. A populationbased prospective cohort study: The HUNT Study. Amer J Gastroenterol 2015;110:393-400.

35. Hansen J.M., Wildner-Christensen M., Schaffalitzky de Muckadell O.B.: Gastroesophageal reflux symptoms in Danish population: a prospective follow-up analysis of symptoms, quality of life, and health-care use. Am J Gastroenterol 2009;104:2394-2403.

36.He J., Ma X., Zhao Y., Wang R., Yan X., Yan H., Yin P., Kang X., Fang J., Hao Y., Li Q., Dent J., Sung J.J., Zou D., Wallander M.A., Johansson S., Liu W., Li Z.: A population-based survey of the epidemiology of symptom-defined gastroesophageal reflux disease: the Systematic Investigation of Gastrointestinal Diseases in China. BMC Gastroenterol 2010;10:94-103.

37. Herrera-López J.A., Mejía-Rivas M.A., VargasVorackova F., Valdovinos M.A.: Capsaicin induction of esophageal symptoms in different phenotypes of gastroesophageal reflux disease. Rev Gastroenterol Mex 2010;75(4):396-404.

38. Hershcovici T., Fass R.: Nonerosive Reflux Disease (NERD) - an update. J Neurogastroenterol Motil 2010;16:8-21.

39. Iwakiri K., Kobayashi M., Kotoyori M., Yamada H., Sugiura T., Nakagawa Y.: Relationship between postprandial esophageal acid exposure and meal volume and fat content. Dig Dis Sci 1996;41:926-930.

40.Jarosz M., Taraszewska A.: Risk factors for gastroesophageal reflux disease - the role of diet. Przegl Gastroenterol 2014;9(5):297-301.

41. Jarosz M.: Choroba refluksowa przełyku. W Najczęstsze choroby górnego odcinka przewodu pokarmowego (red. M. Palka, G. Margas, M. Jarosz), Seria: Praktyka Lekarza Rodzinnego, Wydawnictwo Lekarskie PZWL, Warszawa, 2010;79-105 (in Polish)

42.Jarosz M.: Piramida Zdrowego Żywienia i Aktywności Fizycznej. W Dietetyka. Żywność, żywienie w prewencji i leczeniu. (red. M. Jarosz), IŻŻ, Warszawa, 2016;2017:93-97 (in Polish)

43. Jonaitis L., Kriukas D., Kupcinskas L.: Risk factors for erosive esophagitis and Barrett's Esophagus in a high Helicobacter pylori prevalence area. Medicina (Kaunas) 2011;47(8):434-439.

44.Jozkow P, Wasko-Czopnik D, Medras M., Paradowski L.: Gastroesophageal reflux disease and physical activity. Sports Med 2006;36(5):385-391.

45. Katz P.O., Gerson L.B., Vela M.F.: Guidelines for the diagnosis and management of gastroesophageal reflux disease. Am J Gastroenterol 2013;108:308-328.

46.Keshavarzian A., Polepalle C., Iber F.L., Durkin M.: Esophageal motor disorder in alcoholics: result of alcoholism or withdrawal? Alcohol Clin Exp Res 1990;14:561-566.
47. Lee S.J., Jung M.K., Kim S.K., Jang B.I.: Clinical characteristics of gastroesophageal reflux disease with esophageal injury in Korean: focusing on risk factors. Korean J Gastroenterol 2011;57(5):281-287.

48.Locke G.R. 3rd, Talley N.J., Fett S.L., Zinsmeister A.R., Melton L.J.: Risk factors associated with symptoms of gastroesophageal reflux. Am J Med 1999;106:642-649.

49. Mayer E.M., Grabowski C.J., Fisher R.S.: Effects of graded doses of alcohol upon esophageal motor function. Gastroenterol 1978;75:1133-1136.

50. Mion F., Dargent J.: Gastro-oesophageal reflux disease and obesity: Pathogenesis and response to treatment. Best Pract Res Clin Gastroenterol 2014;28:611-622.

51. Moayyedi P., Talley N.J.: Gastroesophageal reflux disease. Lancet 2006;367:2086-2100.

52.Mohammed I., Cherkas L.F., Riley S.A., Spector T.D., Trudgill N.J.: Genetic influences in gastro-oesophageal reflux disease: a twin study. Gut 2003;52:1085-1089.

53. Murao T., Sakurai K., Mihara S., Marubayashi T., Murakami Y., Sasaki Y.: Lifestyle change influences on GERD in Japan: a study of participants in a Health Examination Program. Dig Dis Sci 2011;56(4):988-992.

54. Murray L, Johnston B, Lane A, Harvey I., Donovan J., Nair P., Harvey R.: Relationship between body mass and gastro-oesophageal reflux symptoms: The Bristol Helicobacter Project. Int J Epidemiol 2003;32:645-650.

55. Nasseri-Moghaddam S, Mofid A, Ghotbi MH, Nouraie M., Ramard A.R., Zaer-Rezaie H., Habibi R., RafatZand K., Malekzadeh R.: Epidemiological study of gastro-oesophageal reflux disease: reflux in spouse as a risk factor. Aliment Pharmacol Ther 2008;28:144-153.

56. Nebel O.T., Castell D.O.: Inhibition of the lower esophageal sphincter by fat - a mechanism for fatty food intolerance. Gut 1973;14:270-274.

57. Nebel O.T., Castell D.O.: Lower esophageal sphincter pressure changes after food ingestion. Gastroenetrol 1972;63:778-783.

58. Nebel O.T., Fornes M.F., Castell D.O.: Symptomatic gastroesophageal reflux: incidence and precipitating factors. Am J Dig Dis 1976;21:953-956.

59. Nilsson M., Johnsen R., Ye W., Hveem K., Lagergren J.: Lifestyle related risk factors in the aetiology of gastrooesophageal reflux. Gut 2004;53:1730-1735.

60.Nirwan J.S., Hasan S.S., Babar Z.D., Conway B.R., Ghori M.U.: Global Prevalence and Risk Factors of Gastro-oesophageal Reflux Disease (GORD): Systematic Review with Meta-analysis. Sci Reports 2020;10:5814-5826.

61. Nocon M., Labenz J., Willich S.: Lifestyle factors and symptoms of gastroesophageal reflux - a population based study. Aliment Pharmacol Ther 2006;23:169-174.

62.Nozu T., Komiyama H.: Clinical characteristics of asymptomatic esophagitis. J. Gastroenterol 2008;4:2731.

63. Oliveria S.A., Christos P.J., Talley N.J., Dannenberg A.J.: Heartburn risk factors, knowledge and prevention strategies: a population-based survey of individuals with heartburn. Arch Intern Med 1999;159:1592-1598.

64.Pandeya N., Green A.C., Whiteman D.C.: Prevalence and determinants of frequent gastroesophageal reflux 
symptoms in the Australian community. Dis Esophagus 2012;25:573-583.

65. Pehl C., Waizenhoefer A., Wendl B., Schmidt T., Schepp $W$., Pfeiffer A.: Effect of low and high fat meals on lower esophageal sphincter motility and gastroesophageal reflux in healthy subjects. Am J Gatsroenterol 1999;94:1192-1196.

66.Piesman M., Hwang I., Maydonovitch C., Wong R.K.: Nocturnal reflux episodes following the administration of a standardized meal. Does timing matter? Am J Gastroenterol 2007;102:2128-2134.

67. Price S.F., Smithson K.W., Castell D.O.: Food sensitivity in reflux esophagitis. Gastroenterol 1978;75:240-243.

68.Randhawa M.A., Mahfouz S.A., Selim N.A., Yar T., Gillessen A.: An old dietary regimen as a new lifestyle change for Gastro esophageal reflux disease: A pilot study. Pak J Pharm Sci 2015;28(5):1583-1586.

69. Rodriguez-Stanley S., Collings K.L., Robinson M., Owen $W$., Miner P.B.: The effects of capsaicin on reflux, gastric emptying and dyspepsia. Aliment Pharmacol Ther 2000;14(1):129-134.

70.Ruhl C.E., Everhart J.E.: Overweight, but not high dietary fat intake, increases risk of gastroesophageal reflux disease hospitalization: the NHNANES I Epidemiologic Follow-up Study. First National Health and Nutrition Examination Survey. Ann Epidemiol 1999;9:424-435.

71. Salvia G., De Vizia B., Manguso F., Iula V.D., Terrin $G$., Spadaro $R$.: Effect of intragastric volume and osmolality on mechanisms of gastroesophageal reflux in children with gastroesophageal reflux disease. Am J Gastroenterol 2001;96:1725-1732.

72.Shahid K., Wasim J., Afsheen F.: Regular post dinner walk; can be a useful lifestyle modification for gastroesophageal reflux. J Pak Med Assoc 2011;61(6):526-530.

73. Shapiro M., Green C., Bautista J.M., Dekel R., RisnerAdler S., Whitacre R., Graver E., Fass R.: Assessment of dietary nutrients that influence perception of intraoesophageal acid reflux events in patients with gastro-oesophageal reflux disease. Aliment Pharmacol Ther 2007;25:93-101.

74. Song J.H., Chung S.J., Lee J.H., Kim Y.H., Chang D.K., Son H.J., Kim J.J., Rhee J.C., Rhee P.L.: Relationship Between Gastroesophageal Reflux Symptoms and Dietary Factors in Korea. J Neurogastroenterol Motil 2011;17:54-60.

75. Śmiechowska M., Cugowska M.: Rola żywności i żywienia w chorobie refluksowej. Bromat Chem Toksykol 2011;44(3):298-304.

76. Terry P, Lagergren J, Wolk A., Nyren O.: Refluxinducing dietary factors and risk of adenocarcinoma of the esophagus and gastric cardia. Nutr Cancer 2000;8(2):186-191.

77. Vakil N., van Zanten S., Kahrilas P., Dent J., Jones R., Global Consensus Group: The Montreal definition and classification of gastroesophageal reflux disease: a global evidence-based consensus. Am J Gastroenterol 2006;101:1900-1920.

78.van Herwaarden M.A., Katzka D.A., Smout A.J., Samsom M., Gideon M., Castell D.O.: Effect of different recumbent positions on postprandial gastroesophageal reflux in normal subjects. Am J Gastroenterol 2000;95:2731-2736.

79. Wang F.W., Tu M.S., Chuang H.Y., Yu H.C., Cheng L.C., Hsu P.I.: Erosive esophagitis in asymptomatic subjects: risk factors. Dig Dis Sci 2010;55:1320-1324.

80.Wang P.C., Hsu C.S., Tseng T.C., Hsieh T.C., Chen C.H., Su W.C., Lin H.H., Wang C.C.: Male sex, hiatus hernia, and Helicobacter pylori infection associated with asymptomatic erosive esophagitis. J Gastroenterol Hepatol 2012;27:586-591.

81. Wang H.Y., Leena K.B., Plymouth A., Hergens M.P., Yin L., Shenoy K.T., Ye $W$.: Prevalence of gastro-esophageal reflux disease and its risk factors in a communitybased population in southern India. BMC Gastroenterol 2016;16:36-41.

82.Wang J.H., Luo J.Y., Dong L., Gong J., Tong M.: Epidemiology of gastroesophageal reflux disease: a general population-based study in Xi'an of Northwest China. World J Gastroenterol 2004;10(11):1647-1651.

83. Watanabe Y, Fujiwara Y., Shiba M., Watanabe T., Tominaga K., Oshitani N., Matsumoto T., Nishikawa H., Higuchi K., Arakawa T.: Cigarette smoking and alcohol consumption associated with gastro-oesophageal reflux disease in Japanese men. Scand J Gastroenterol 2003;38(8):807- 811.

84. Wildi S.M., Tutuian R., Castell D.O.: The influence of rapid food intake on postprandial reflux: studies in healthy volunteers. Am J Gastroenterol 2004;99:16451651.

85. Yamamichi N., Mochizuki S., Asada-Hirayama I., Mikami-Matsuda R., Shimamoto T., Konno-Shimizu M., Takahashi Y., Takeuchi C., Niimi K., Ono S., Kodashima S., Minatsuki C., Fujishiro M., Mitsushima T., Koike $K$. Lifestyle factors affecting gastroesophageal reflux disease symptoms: a cross-sectional study of healthy 19864 adults using FSSG scores. BMC Med 2012;10:4555.

86.Yang S.Y., Lee O.Y., Kim H.E., Chang Y.K., Yoon B.C., Choi H.S., Chung Y.G., Cho C.H.: Dietary related risk factors and quality of life in patients with gastroesophageal reflux disease. Korean J Med 2006;70:627-635.

87. Zheng Z., Nordenstedt H., Pedersen N.L., Lagergren $J$., Ye $W$ : Lifestyle factors and risk for symptomatic gastroesophageal reflux in monozygotic twins. Gastroenterol 2007;132:87-95.

88.Ziótkowski B.A., Pacholec A., Kudlicka M., Ehrmann A. , Muszyński J.: Prevalence of abdominal symptoms in the Polish population. Przegl Gastroenetrol 2012;7(1):20-25.

Received: 05.01.2021

Accepted: 29.01.2021

This article is available in Open Access model and licensed under a Creative Commons Attribution-Non Commercial 3.0.Poland License (CC-BY-NC) available at: http://creativecommons.org/licenses/by-nc/3.0/pl/deed.en 